\title{
Shifting Journalistic Ethics in the Internet Age, Case Study: Violation of Journalistic Ethics in Journalistic Products and Journalist Behavior in Online Media
}

\author{
Rani Dwi Lestari \\ Universitas Mercu Buana Yogyakarta \\ author correspondence: aieramaharani@gmail.com
}

_. DOI: https://doi.org/10.18196/jkm.1123027

Article Info

Article history:

Received 05 Sep 2019

Revised 12 Oct 2019

Accepted 13 Nov 2019

\section{ABSTRACT}

The internet era has significantly contributed to the dynamic development of journalism. The consequences of the presence of the internet in journalism change at least two essential things, namely the presentation of journalistic products and the behavior of journalists. The internet has given rise to new media platforms, namely online media and changing information dissemination to be faster and more massive. The internet also affects journalist behavior in the field in the process of searching, processing and disseminating information. On the one hand, journalistic ethics as signs that regulate journalistic products and journalist behavior has shifted in the era of internet journalism. The Journalistic Code of Ethics is considered only to regulate the ethical side of conventional journalism practices and does not cover online journalism. This is what makes many violations of journalistic ethics in online media. This study aims to find out how the shift in journalistic ethics in online journalism on www.tribunjogja.com and www.detik.com in 2019. This research will also describe how forms of journalistic ethics violate in online media both in terms of journalistic products and journalist behavior. The results of this study are expected to provide input to the articles in the Journalistic Code of Ethics to be applied not only in the practice of conventional journalism but also in online journalism.

Keywords: Internet, Journalism, Online Media, Journalistic Ethics, News.

\section{ABSTRAK}

Era internet telah berkontribusi besar terhadap perkembangan jurnalisme yang dinamis. Konsekuensi dari kehadiran internet dalam jurnalisme mengubah setidaknya dua hal dasar, yaitu penyajian produk jurnalistik dan perilaku jurnalis. Internet telah memunculkan platform media baru, yaitu media online dan mengubah penyebaran informasi menjadi lebih cepat dan lebih masif. Internet juga memengaruhi perilaku jurnalis di lapangan dalam proses pencarian, pemrosesan, dan penyebaran informasi. Di satu sisi, etika jurnalistik sebagai tanda yang mengatur produk jurnalistik dan perilaku jurnalis telah bergeser di era jurnalisme internet. Kode Etik Jurnalistik dianggap hanya mengatur sisi etis dari praktik jurnalisme konvensional dan tidak mencakup jurnalisme online. Inilah yang membuat banyak pelanggaran etika jurnalistik di media online. Penelitian ini bertujuan untuk mengetahui bagaimana perubahan etika jurnalistik dalam jurnalisme online pada www.tribunjogja.com dan www.detik.com tahun 2019. Penelitian ini juga akan menggambarkan bagaimana bentuk-bentuk etika jurnalistik dilanggar di media online baik dalam hal produk jurnalistik maupun perilaku jurnalis. Hasil penelitian ini diharapkan dapat memberikan masukan kepada artikel-artikel dalam Kode Etik Jurnalistik untuk diterapkan tidak hanya dalam praktik jurnalisme konvensional tetapi juga jurnalisme online.

Kata kunci: Internet, Jurnalisme, Media Online, Etika Jurnalistik, Berita 


\section{INTRODUCTION}

Journalistic activities in the field, ranging from fact collection to journalistic work, have experienced rapid dynamics along with technological advances and easy access to information. Changes occur mainly because of the emergence of the internet which makes the process in journalism like the two sides of a coin. One side provides positive benefits, but on the other hand, can contribute to harmful consequences.

As one form of new media, online media has become the choice of many people to access information. With various advantages possessed, the public is increasingly facilitated to get access and update information in online media without having to be barred by distance and time. If previously printed media claimed to be a form of in-depth journalism that was able to display news in a long way, now with the accompanying technology, online media does not even have page boundaries to expose comprehensive, long and deep coverage. This fact is increasingly placing online media as the prima donna of the digital age community to access information (Lestari, 2018).

The increasing interest of the community towards online media has led to various online media sites that seem to be mushrooming and proliferating. Data from the press council shows that since the beginning of 2013 until 2017 the number of cyber media or online media has spiked, from 47,000 media in Indonesia today, 43,300 of which are cyber media or online media. This is what the press council later called the explosion of cyber media growth (Dewan Pers, 2017).

Of the many online media which are estimated to have increased in number, only a small percentage have fulfilled the verification of the press council. Even though we do not have the exact data until the factual verification process is completed at the end of 2018 , referring to the data collection process that was carried out by the Press Council and later published as a book titled "2015 Press Data", online media that fulfill the requirements is called a press company are only 168 press companies. It means that there are only $0.04 \%$ of online media that are worthy of being called professionals (Buletin Etika Dewan Pers, 2017).

Various changes, especially in the field of internet technology, resulted in media tasks becoming heavier, notably after quick changes occur in the news. The way that news is collected and presented changes, now faster, freer and cheaper - faster, looser and less expensive. Changes in technology have been so fast that the media market share has declined and has become increasingly narrow (Ishwara, 2014).

The internet has provided convenience in the journalistic process, starting from the search for the initial idea of the coverage that can be facilitated by the power of internet-based data search engines. Until the work process in the field, the internet facilitates journalists in extracting data in the field, distributing journalistic works to editorial desks to disseminating journalistic work to the public more massively without being bound by the distance of space and time. On the other hand, the internet with all its facilities also contributes to the negative side, especially concerning the practice of applying journalistic ethics that a journalist must hold firm in carrying out his profession, including the journalistic products produced.

The practice of non-professionalism online media itself can be seen from various sides, ranging from the unverifiable press company that overshadowed, the behavior of journalists in it, until journalistic products or news published by the media. Multiple forms of violations primarily related to journalistic ethics are often encountered.

The Press Council regulates regulations for press members in the form of the Journalistic Code of Ethics. Code of Ethics is a moral reference to monitor the behavior of a journalist. Implementation of the journalistic code of ethics can be one of the benchmarks of journalism professionalism in carrying out their duties journalism. Besides its function as a media of information, journalism also functions to educate and write. Furthermore, everything that is produced by journalists must contain educational content (Tania, 2018).

The presence of the internet in the realm of journalism seems to bring it in a confusing state. Meanwhile, the pressure to operate efficiently is even stronger. In desperation to attract interested people, the press sometimes moves towards sensations, entertainment, and opinions. The result for journalism is the violation of press ethics, the decline of audiences and public confidence (Ishwara, 2014). Often, the characteristics of the internet through the practice of reporting in online media have implications for violating journalistic ethics. This happens because there was a shift between ethics that formerly only regulated conventional media, not internet-based, to regulate the practice of online journalism. 
Although the articles in journalistic ethics are considered to still quite relevant, they are used to regulate the ethics of online media, but in practice, there are several violations of journalistic ethics that are actually found in the practice of online journalism. The press council itself as the regulator that regulates media regulation and the press has compiled guidelines for cyber media reporting as signs in regulating the practice of journalism in online media. However, this is dominated by rules that are technical in nature and less regulating in terms of ethics in both journalistic products and the behavior of media workers.

On the other hand, related to sanctions in violating journalistic ethics in online media is also still not firm. In some cases, the press council only provides recommendations regarding sanctions given for violating journalistic ethics. The implementation of sanctions is handed back to media institutions and press organizations. The problems that arise here are related to the implementation of sanctions that have minimal supervision and evaluation and tend to be ignored. This is what makes the issue of violation of journalistic ethics in online media continues to roll and experience omission.

Edward Spence and Peter Denyer-Simmons (2006) reveal that the main issue regarding journalistic ethics is fraud and trust. From here comes the old problem, but in a new container. The issue of journalistic ethics is a problem that has long been discussed, but it has become new because it occurs in new media or new media with a variety of characteristics. Moreover, the rules regarding journalistic ethics in online media are not yet clear and straightforward. Until now, the rules regarding journalistic ethics compiled by the new Press Council in the form of guidelines for reporting on cyber media are not yet in the form of a code of ethics (Santoso, 2018).

The issue of this code of ethics is crucial for a profession, especially journalists because they are not only required to develop their professional idealism but also a significant media effect for the public. The code of ethics is essential because it is part of the professionalism of journalists (Lewi, 2014). The application of the journalistic code of ethics itself must be carried out thoroughly in journalistic activities on various media platforms both print, electronic and online.

This is what will be described descriptively in this study related to how the shift in journalistic ethics is seen from the side of violations that occur in the era of internet journalism. This study will try to observe how journalistic products produced by online media are viewed from an ethical perspective, including conducting interviews with journalists in the field who practice online journalism. The results of this study are expected to contribute to the articles in the journalistic code of ethics to accommodate the practice of online journalism. The violations of journalistic ethics, both from the behavior of journalists and the resulting journalistic products can be minimized. In addition, this study also seeks to map the violations of online journalistic ethics that often do not get strict and repeated sanctions due to inadequate rules.

Based on literature searches, both print and online, there are several previous studies related to the ethics of online journalism. One of them is Christiany Judhita with the title Objectivity of News and Journalistic Ethics in Media Online: Cases of Recruitment of BUMN Employees. This study discussed the objectivity of reporting in online media in the case of banning headscarves for BUMN employees. Of the six online media studied, namely Okezone.com, Sindonews.com, Goriau.com, Tribunnews.com, Harianterbit, and Republika Online, it was concluded that objectivity applies in online media, such as no checks and checks, not cover both sides, and not balanced although some of these media sites then finally gave clarification from the Ministry of SOEs that denied the issue (Judhita, 2016).

Other studies related to the ethics of journalism in online media were also conducted by Yohanes Widodo with the research title Questioning the Ethics of Contemporary Journalism: Learning from OhmyNews. This article explored journalism ethics, credibility, and contemporary journalism through a case study of Ohmynews - citizen journalism developed in South Korea. This research produced three solutions offered in upholding ethics for citizen journalism in online media. First, developing education and training for citizen journalism. Second, building collaboration between professional journalism and citizens. Third, in their task, the journalist must be based on nine journalism elements. Idealism media as social control and education for society can be practiced (Widodo, 2010).

Meanwhile, research on online media journalistic ethics was also conducted by Didik Haryadi Santoso and Rani Dwi Lestari, who discussed the Application of Journalistic Ethics in Political Coverage in Online Media. This study discussed the application of journalistic ethics in online media, especially in the political reporting of the DKI Jakarta Pilkada in 2017. This research was conducted in five national online media, including sindonews.com, mediaindonesia.com, kompas.com, republika.co.id, and tribunnews.com. The study found several violations of journalistic ethics. In 
addition, the application of journalistic ethics in online media in the election of the Governor of DKI Jakarta has not been optimal. The causes are economic and political factors (Santoso, 2018).

The code of ethics in the realm of journalism is a moral standard for journalists to be able to work parallelly with truth and conscience. Because the journalist profession is fairly carefully related to matters relating to the interests of the wider community, journalist professions have considerable responsibility in creating a democratic life. Where the press as the fourth pillar of democracy is present as a source of power, other powers are responsible for conveying factual information for common interests. In the era of mass media convergence accompanied by rapid technological advancements, journalists must take this opportunity responsibly because the public still wants the credibility and diversity of the news, including in online media.

\section{METHODS}

This study used qualitative methods with a case study approach. To be specific, it was explanatory descriptive case studies. In general, case studies are strategies that are more suitable when the subject of the research question concerns how and why. If the researcher has little opportunity to control the events to be investigated, the focus of his research lies in contemporary (inner) phenomena inside a real-life context (Yin, 2013).

Data collection in this study collaborated three methods of data collection of case studies namely interviews, observation, and documentation. Interviews in this study used the technique of depth interviews or in-depth interviews with open and semistructured interview types. The author prepared several key question points and deepens again when found interesting facts from the interviewees' answers or research subjects. This made it possible to get more complete and comprehensive field data.

Furthermore, the findings of interviews and observations were complemented by documentation methods to strengthen data. Data analysis in this study conducted through several stages, namely data collection, data reduction, and data presentation.

\section{RESULTS AND DISCUSSION}

\section{The shift in Journalistic Ethics from the Side of Journalistic Products}

Journalistic products can be widely understood as pieces of work from the media or the press in the form of news and other works that are also disseminated by the mass media which are press institutions. However, specifically, journalistic products refer to what is called journalistic work or news only. The news itself can be understood as an essential fact or event and has a significant impact on the public and disseminated through the mass media. News is the main product of journalism in meeting the instinctive needs of people who are curious in providing information to audiences about an event. News sought by a reporter is a report about the facts involved in an event, but not the essence of the event itself (Suhandang, 2016).

News is a journalistic product produced by the mass media regarding a fact that has essential values and extraordinary values for the community. News is a product of a press company that has a universal goal of educating, entertaining, social control (mediating), and providing information. The news concept is pretty much mentioned. The core of the news is information or facts that are extraordinary or special for the public. Information can be made into the news if it meets the eligibility criteria for the news, namely a combination of news value and editorial policy. News can also be seen as an arrangement of facts about current events that attract people's attention, meaning important to the audience (Susilastuti, 2013).

In the realm of journalism, we are familiar with two types of news in the mass media, namely Straight News / Hard News or hard news and Soft News or light news. Straight News is also called warm news, which has an essential meaning for the public because it usually contains current events, just happened or is happening. While soft news is typically considered to be less critical news because the content is entertaining, sometimes it also provides essential information.

On the other hand, Luwi Ishwara argued that there are at least two types of news: event centered news that typically presents recent warm events and is generally not interpreted, with minimal context, not related to other situations and circumstances. The main idea is that a topic is not feasible to become a story before something happens. The second type is process-centered news that is 
presented with an interpretation of the conditions and situations in society that are connected in a broad and exceeding time context (Ishwara, 2014).

In terms of journalistic products or news produced by online media, the forms of violations that are often carried out can be classified. Some of them are:

1. Accuracy

The issue of accuracy is a dilemma in the practice of journalism in online media. The characteristics of online media that prioritize speed often contradict the verification process which requires time to achieve accurate reporting. Business clashes and public interests are often a problem where online media is required to be the fastest and most updated news reference while, in the process of constructing a fact of events to be news, it requires steps to test accuracy. In practice, online media often uses news update weapons as part of the fact verification process. The problem that arises is, should not the news consumed by the public be accurate and verified? It is not precisely the verification that took place when the report was published.

2. Cover both Sides

Ideally, balanced reporting in terms of technical preparation of news presents at least two sides of the resource person who are usually at odds with each other. It would be even better if journalistic works not only cover both sides but also cover multiple sides so that the audience as consumers of information would know the construction of facts and events as a whole. However, in the practice of journalism in online media, it often only uses one side of the resource person in each report. The reason for the update is rolled out as justification. In fact, not always will online media readers follow news updates indirectly when they are presented from one side, it will obscure the real context of the problem.

3. Journalistic Cloning and Plagiarism

Cloning journalism can be understood as an activity of exchanging news sources conducted by journalists in producing journalistic work. The news source in question can be in the form of interview records, journalist interview records, and news forms that are sent between journalists. It is called cloning journalism because the journalistic work produced is not merely a copy that is very similar but can consist of several variants. For example, news cloning is produced from the results of interviews with other people and then given additional alternative sources. There is also a form of cloning news by combining the results of journalist interviews with one another, or even combine the news that has been prepared from several other journalists, to be compiled into a new journalistic work (Lestari, 2015).

4. Self Plagiarism

The concept of self-plagiarism is actually a derivative of the types of plagiarism presented by Henry Soelistyo (2011) where this type of plagiarism essentially puts the author in the wrong position because of lying to his readers. Of the various possible problems, there are two forms of actions, namely the publication of writing or articles in more than one media and the act of recycling text.

In some cases, the repetition of an article is sometimes needed when the issue is reappointed in the discussion. Repetition is required to get more attention. This is often a necessity in the media. For example, for the purposes of correction, the author must repeat the part of the previous writing as a reference for discussion. That way rewriting becomes relevant to make the discussion becomes focused and not deviate. In addition, the use of text or phrases from previous writings is sometimes also needed to support comparative reviews (Soelistyo, 2017).

On the one hand, in the practice of journalism, especially in online media, repetition of news with the same substance but different titles makes the reader protest. This is considered detrimental and a waste of time. The readers feel that they have been tricked with a different title but the same substance. There are many ways to identify the same thing even when it comes to very technical language (Jef Akst, 2010). A practice like this is considered a lie and is very unethical. The question is, why are editors unable to prevent self-plagiarism like this? The editorial staff can also be considered guilty and must be held accountable. Dialectics as discussed above actually represent the discourse on how severe the problem of selfplagiarism is.

5. Clickbait Journalism 
Clickbait journalism is very closely related to the practice of self-plagiarism in the news in online media. In the concept of clickbait journalism, journalists and editors often break up news that commonly has been previously reported into several pageviews. The aim is fishing the click of the readers.

In practice, one news in online media is divided into several pageviews to be read in full. Readers are compelled to move page after page to be able to read and know the facts that they want to convey in the news. This practice is performed because of the principle that advertisers will see online media based on high traffic. This traffic can be achieved maximally when online media can capture as many clicks as possible from the reader. However, it appears unethical to impose readers to change pages just for the sake of one news that is sometimes also presented before.

Clickbait journalism is not only limited to breaking pages in one news. In another type, clickbait journalism also often causes readers to click by posting controversial and sensational news titles. Unfortunately, news content is often not even related to the title or does not represent the contents of the actual title. In terms of ethics, the reader is clearly the one who is at a disadvantage because trapping information has been presented.

\section{The shift in Journalistic Ethics from the Side of Journalist Behavior}

Journalistic ethics regulates at least two fundamental sides in the journalistic process. Firstly, related to journalistic works produced by the media, and, secondly, by the behavior of journalists or media institutions. In terms of journalist behavior in the field, it is often difficult to know whether the violations that occur are related to journalistic ethics. This is because ethics violations from the journalist side can only be known to one another between journalists or at least those who are close to the journalists' daily lives.

The difficulty of detecting ethical violations in terms of journalist behavior is also due to the ignorance of ethical understanding itself. Thus, journalists often are not aware of ethical violations committed or it is considered as habits that are naturally done. Some forms of ethical breaches in terms of journalist behavior, especially in the era of internet journalism include:

1. Pack Journalism

The journalism pack can be simply understood as journalism carried out by journalists in a group and is characterized by uniformity of reporting and lack of journalist initiative in finding independent news sources. Crowd journalism or pack journalism is a tendency for journalist behavior to flock to one and the same news source. This tendency arises because of the beat system that is applied by the media by placing journalists on individual posts based on geographical territory and rubric.

Jonathan Matusitz and Gerald-Mark Breen, in their research Unethical Consequences of Pack Journalism (2007), provided several definitions of pack journalism: "Pack journalism, a widespread media practice where large groups of reporters collaborate to cover the same story, should be abolished, or at least lessened in frequency ". Matusitz said that there are at least seven consequences that will emerge as an impact of pack journalism, namely: (1). Lazy journalism, (2). Impact on the public (readers and viewers), (3). Interfering with privacy, (4). Loss of news independence, (5). Loss of credibility in the news, (6). Slander news, (7). Economic inefficiency.

2. Culture of News Cloning

Journalism cloning concerns not only about the news produced by journalists but also be seen from the side of journalist behavior in the field in producing news. The phenomenon of cloning journalism that occurs in Indonesia turns out to have similar patterns to pack journalism. This Journalism Pack is closely related to cloned journalism because the patterns that occur are very similar to cloning behavior.

Everyone in journalism steals from everyone else. Opinion writers are packs of who steal ideas, facts, opinions to add insight to an issue. Newspaper plagiarism is the most important editor for object remorselessly to copying stealing material. (Paul, 2013).Cloning journalism itself has been included in three violations of professional ethics, which are most often carried out by journalists. Paramita (2013: 6), in his research, stated that three violations of 
professional ethics, which are often carried out by journalists include cover both sides, the practice of giving envelopes and plagiarism or cloning problems.

Table 1. Types of Cloning Journalism

\begin{tabular}{|c|c|c|c|c|}
\hline $\begin{array}{l}\text { Cloning by } \\
\text { Method }\end{array}$ & $\begin{array}{l}\text { Cloning by } \\
\text { Process }\end{array}$ & $\begin{array}{c}\text { Cloning } \\
\text { Based on The } \\
\text { Level }\end{array}$ & $\begin{array}{c}\text { Cloning based } \\
\text { on substance }\end{array}$ & $\begin{array}{c}\text { Cloning Based } \\
\text { on the } \\
\text { Presence of } \\
\text { Journalists }\end{array}$ \\
\hline $\begin{array}{l}\text { 1. Take raw } \\
\text { material } \\
\text { 2. Take raw } \\
\text { and material } \\
\text { process it } \\
\text { 3. Take raw } \\
\text { and partially } \\
\text { processed }\end{array}$ & $\begin{array}{l}\text { 1. } \begin{array}{l}\text { Before } \\
\text { becomin }\end{array} \\
\text { g news } \\
\text { 2. After } \\
\text { becomin } \\
\text { g news }\end{array}$ & $\begin{array}{ll}\text { 1. } & \text { Totally } \\
\text { same } \\
\text { 2. } & \text { Some } \\
\text { 3. } & \text { One } \\
& \text { paragrap } \\
& \text { h } \\
\text { 4. } & \text { One } \\
\text { quote }\end{array}$ & $\begin{array}{ll}\text { 1. } & \text { Full } \\
\text { 2. } & \text { Partial }\end{array}$ & $\begin{array}{ll}\text { 1. } & \text { Present } \\
\text { 2. } & \text { Not Present }\end{array}$ \\
\hline
\end{tabular}

3. News Aggregator / Curation Journalism

News Aggregator can simply be understood as a collection of news from various sources that are presented in the form of links through a particular website or site. The News Aggregator is deliberately discussed because of its relevance to cloned journalism. That is whether the aggregate practice of the news is a form of copyright infringement on journalistic works that is very close to plagiarism. To understand it further, it is an excellent idea to analyze some definitions of a news aggregator, one of which is the research that Kimberly Isbell has done: "At its most basic, a news aggregator is a website that takes information from multiple sources and displays it in a single place" (Isbell, 2010:2).

From the definition given, it can be explained simply that the news aggregator is a website that provides information from various sources and is presented in one place. In accordance with what is shown so far, often the news aggregator is not the original owner of specific information or news but only collects various sources.

News Aggregator, according to Kimberly, is included in several forms. He classifies it into four types including Feed Aggregators, Specialty Aggregators, User-Curated Aggregators, and Blog Aggregators.

Feed Aggregators is the closest to the traditional conception of a news aggregator, namely, a website that contains material from many sites organized into various 'feed' typically arranged by source, topic or story. Feed Aggregators often draw their material from a particular type of source, such as news websites or blogs, although some feed aggregators will contain content from more than a type of source" (Isbell, 2010:2).

Specialty aggregators are a website that collects information from a number of sources on a particular topic or location. User-Curated Aggregators is a website that features usersubmitted links and portions of text taken from a variety of websites. Often the links on a user-curated aggregator will be culled from a wider variety of sources than most news aggregators and will often include links to blog posts and multimedia content. Blog aggregators are websites that use third-party content to create a blog about a given topic (Isbell, 2010:3).

Furthermore, user-curated aggregators are websites that feature user-submitted links and sections of text taken from various websites, even often links to user-link aggregators are taken from a wider variety of sources than most news aggregates and often include links to blog posts and news content. The latter type of blog aggregators are websites that use thirdparty content to create a blog about a particular topic.

In practice, the news aggregator often reaps controversy, especially related to the legality of presenting information and the authenticity of ownership of the content of the news presented. In Indonesia, the provisions concerning this matter are stated in the regulation of Press Council number 1 of 2012 concerning guidelines for reporting on cyber media. Cybermedia 
itself is defined as all forms of media that use internet vehicles and carry out journalistic activities. On the fourth point, the guideline stated that, if certain cyber media news is disseminated by other cyber media, then:

a. The responsibility of newsmaker cyber media is limited to news published on the cyber media or cyber media that is under its technical authority.

b. Correction of news carried out by a cyber media must also be carried out by other cyber media citing news from the corrected cyber media

Media that disseminates news from a cyber media and does not make corrections to the news according to those carried out by cyber media owners and/or newsmakers, is fully responsible for all legal consequences of the news that is not corrected.

\section{CONCLUSION}

In the era of internet journalism, journalistic ethics is a guideline that is still gray, primarily if it is associated with the characteristics of journalism in online media which is different from conventional journalism. Ethical shifts occur when pre-existing articles have not been able to regulate what constituting a violation tendency in online media that was not encountered before the existence of the internet. The shifting violations can be seen in terms of journalistic products and journalist behavior. In terms of journalistic products, the ethical shift that occurred was, firstly, the issue of accuracy, which experienced a shift in meaning when applied in online media, which assumed that accuracy could be done piece by piece with system updates. Secondly, both sides of the cover are also understood to be done with system updates, while readers do not necessarily update. The third relates to cloning news where it is difficult to distinguish which news is the work of original journalists and the results of cloning. Fourth, self-plagiarism that is related to recycling the news that has been aired before. Finally, clickbait journalism that is only possible in the era of online journalism by dividing pageviews to capture clicks includes making sensational titles that often do not match the content of the news.

In terms of journalist behavior, the shift in ethics in the era of online journalism consists of, first, the culture of pack journalism that has an impact on the practice of journalists themselves and the resulting journalistic products. Second, the cloning culture between each other is increasingly facilitated by the existence of the internet. The third is the News Aggregator which obscures the function of journalists in the field because it only uses an internet-based system. The media can arrange a story without having to go to the field.

With the tendency of shifting violations of journalistic ethics in this era of internet journalism, concrete steps are needed to be able to enforce the rules regarding the practice of online media journalism ethics. One of them is by compiling articles on journalistic ethics that are adjusted to the characteristics of online journalism practices. This is intended to minimize violations of ethics and restore the main essence of journalism, namely the truth and public interest.

\section{REFERENCES}

Buletin Etika Dewan Pers. (2017). Banyak Penjahat Menumpang Kebebasan Pers. Dewan Pers: Jakarta. Desember 2017.

Isbell, Kimberly. (2010). The Rise of The News Aggregators: Legal Implications and Best Practices, The Berkman Center of Internet and Society. Hardvard University

Ishwara, Luwi. (2014). Jurnalisme Dasar. Kompas Media Nusantara: Jakarta.

Jef Akst. (2010). When is Self Plagiarism OK?. The Scientist Magazine 12, The Nutshell, September $9,2010$.

Juditha, C. (2016). Obyektivitas Berita dan Etika Jurnalistik di Media Online: Kasus Rekrutmen Karyawan BUMN News, E-Journal Pekommas, 1(1), 1-12.

Jurnal Dewan Pers Edisi 15. (2017). Bisnis Media dan Jurnalisme di Persimpangan. Dewan Pers: Jakarta.

Lestari, Rani Dwi. (2015). Jurnalisme Kloning, Praktik Plagiarisme Karya Jurnalistik di Kalangan Jurnalis. Thesis. UGM. 
Lestari, Rani Dwi. (2018). New Media \& Komunikasi Politik: Self Plagiarism Pada Pemberitaan Politik di Media Online dalam Perspektif Etika Jurnalistik. Mbridge Press: Yogyakarta.

Lewi, O. (2014). Penerapan Kode Etik di Kalangan Jurnalis. Jurnal Ilmu Komunikasi UAJY, 11(1), 81-92.

Matusitz, Jonathan., Gerald Mark Breen. (2007). Unethical Consequences of Pack Journalism. Global Media Journal Vol. 6.

Paramita, Eviera. (2013). Pemahaman Wartawan Terhadap Etika Profesi. Jurnal Jurusan Ilmu Komunikasi Fakultas Ilmu Sosial dan Ilmu Politik Universitas Brawijaya, Malang.

Paul Lewis, Norman. (2013). Idea Plagiarism, Journalism's Ultimate Heist. Department of Journalism, University of Florida.

Robert K.Yin. (2013). Studi Kasus Desain \& Metode. Rajawali Pers: Jakarta.

Santoso, Didik Haryadi \& Rani Dwi Lestari. (2018). Penerapan Etika Jurnalistik dalam Pemberitaan Politik di Media Online. Jurnal Pekommas, 3(2), 203-212.

Soelistyo, Henry. (2011). Plagiarisme: Pelanggaran Hak Cipta dan Etika. PT Kanisius, Yogyakarta.

Soelistyo, Henry. (2017). Self Plagiarism, Sebuah Pergumulan Paradigmatik. PT Kanisius: Yogyakarta.

Spence, E. \& Simmons P. D. (2006). The Practice And Ethics Of Media Release Journalism. Australian Journalism Review, 28(1), 167-181.

Suhandang, Kustadi. (2016). Pengantar Jurnalistik: Seputar Organisasi, Produk, dan Kode Etik. Bandung: Nuansa Cendekia.

Susilastuti, DN, Kurnia Arofah. (2013). Strategi Pemberitaan dan Pemilu 2014: Sebuah Analisis Kritis. Prosiding Konferensi Nasional Komunikasi: Potret Media dalam Politik Indonesia. Universitas Mercu Buana Jakarta. Hal: 18-19

Tania, Rizki, dkk. (2018). Peranan Self Regulation Di Tengah Konstelasi Industri Media Pada Harian Republika. Komunikator, 10(1), 48-59.

Widodo, Yohanes. (2010). Menyoal Etika Jurnalisme Kontemporer: Belajar dari OhmyNews. Jurnal ASPIKOM, 1(1), 1-124. 